\title{
Antonio Panaino. "The Conceptual Image of the Planets in Ancient Iran and the Process of Their Demonization: Visual Materials and Models of Inclusion and Exclusion in Iranian History of Knowledge"
}

Alessia Zubani

\section{OpenEdition}

Journals

Édition électronique

URL : https://journals.openedition.org/abstractairanica/54317

DOI : 10.4000/abstractairanica. 54317

ISSN : 1961-960X

Éditeur :

CNRS (UMR 7528 Mondes iraniens et indiens), Éditions de l'IFRI

Référence électronique

Alessia Zubani, «Antonio Panaino. "The Conceptual Image of the Planets in Ancient Iran and the Process of Their Demonization: Visual Materials and Models of Inclusion and Exclusion in Iranian History of Knowledge" », Abstracta Iranica [En ligne], Volume 42-43| 2021, document 4, mis en ligne le 30 décembre 2021, consulté le 27 décembre 2022. URL : http://journals.openedition.org/ abstractairanica/54317 ; DOI : https://doi.org/10.4000/abstractairanica.54317

Ce document a été généré automatiquement le 27 décembre 2022.

Tous droits réservés 


\title{
Antonio Panaino. "The Conceptual Image of the Planets in Ancient Iran and the Process of Their Demonization: Visual Materials and Models of Inclusion and Exclusion in Iranian History of Knowledge"
}

\author{
Alessia Zubani
}

\section{RÉFÉRENCE}

Antonio Panaino. "The Conceptual Image of the Planets in Ancient Iran and the Process of Their Demonization: Visual Materials and Models of Inclusion and Exclusion in Iranian History of Knowledge", NTM Zeitschrift für Geschichte der Wissenschaften, Technik und Medizin 28, 2020, p. 359-389.

1 En s'appuyant sur un corpus des sources iconographiques différentes, incluant aussi des documents provenant de la Chine (e.g., Dunhuang), ainsi que des matériels linguistiques et textuels, l'A. se penche sur la question de la représentation des planètes et des deux luminaires dans le monde iranien ancien en explorant l'origine de leurs dénominations et rôles astrales. De plus, il examine les raisons qui sous-tendent leur démonisation dans les traditions zoroastriennes et manichéennes. Il propose ainsi une nouvelle étude exhaustive sur le sujet, prenant en compte la circulation des savoirs scientifiques et des traditions iconographiques concernant la représentation de corps célestes dans l'espace eurasiatique ancien et médiéval. 


\section{AUTEURS}

ALESSIA ZUBANI

Labex HaStec, EPHE-PSL 